\title{
AN INLAND WATERWAY FREIGHT SERVICE IN COMPARISON TO LAND-BASED ALTERNATIVES IN SOUTH-EASTERN EUROPE: ENERGY EFFICIENCY AND AIR QUALITY PERFORMANCE
}

\author{
Ernestos Tzannatos ${ }^{1}$, Basil Tselentis ${ }^{2}$, Alkis Corres ${ }^{3}$ \\ ${ }^{1,2}$ Dept of Maritime Studies, University of Piraeus, Greece \\ ${ }^{3}$ Dept of Shipping, Trade and Transport, University of the Aegean, Greece
}

Submitted 7 April 2014; resubmitted 3 July 2014; accepted 18 July 2014

\begin{abstract}
Towards the strive of developing sustainable freight transport networks in Europe, the EU and the developing South-Eastern Europe in particular, this paper initially examines the feasibility of establishing a navigable link along the Axios-Morava waterway, for freight transport between the Eastern Mediterranean Sea (via the Aegean) and the Danube River, and then proceeds with its energy and air quality comparison with the competing modes of rail and road. It was found that this waterway service is technically feasible and offers an energy and carbon efficient alternative to road-borne and rail-borne freight. However, the land-based services were found to be superior with regard to their impact upon the air quality of the region, mainly attributed to the stricter emission standards applicable to these transport modes. Finally, it is proposed to build on the ongoing international policy and funding interest in this project in order to implement all the necessary infrastructural and operational changes which will make the proposed waterway service a commercially and environmentally sustainable freight transport alternative in South-Eastern Europe.
\end{abstract}

Keywords: freight transport; modal shift; inland navigation; river transportation; inland waterway; sustainable transport; energy; emissions.

\section{Introduction}

During the course of the last three decades, international trade has increased at a rate much faster than the growth in global Gross Domestic Product (GDP) and in relation to 1975 the increase of the former has been nearly double to that of the latter (UNCTAD 2013). During the last decade this trend was intensified through the rapid economic growth of east Asia and the establishment of significant seaborne freight flows between the FarEast (mainly China) and the West (USA and Europe) through the transpacific and east-west (via the Mediterranean) routes (Fig. 1).

For Europe and particularly for the EU, this eastward shift in trade continues to be predominately served through the northern range ports and their logistical chains utilizing and building on the investments made in support of the previously dominant Europe-USA trade. Although there are signs of correction in this NorthSouth imbalance of extra-European trade flows, mainly evident through the increased port throughput in the western Mediterranean basin, northern gateways have in general retained their ability to counter the proxim- ity advantage of Mediterranean ports for the Asia trade (Gouvernal et al. 2012).

However, the need to strengthen the role of the European ports of the Mediterranean region in international trade is now becoming urgent for ensuring sustainable growth within the European continent as a whole and that of EU in particular (Costa 2013). This urgency is intensified with regard to the eastern Mediterranean basin, as the increased trade demand associated with the EUenlargement into eastern and South-Eastern Europe and the recent economic growth observed in all the countries of this region has to be met.

As the seaborne trade between the Far East and Europe via the East-Med is rapidly expanding, the new manufacturing and consuming centers established throughout the eastern region of Central Europe seek the support of nearby and easily accessible trade gateways. The compounded influence of the eastward shift of both the global and European economic centres of gravity highlights the importance of the East-Med European ports in EUs strive to develop a competitive and resource efficient freight transport system.

Corresponding author: Ernestos Tzannatos

E-mail: et@unipi.gr 


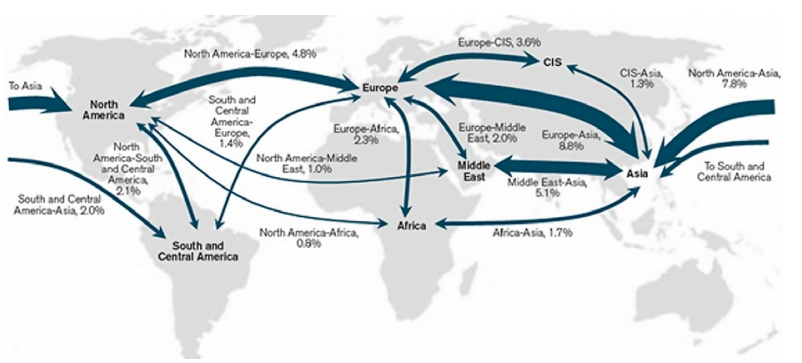

Fig. 1. Percentage share of international trade flows in 2011 (Costa 2013)

In this respect, the latest White Paper (EC 2011), sets a range of specific targets including modal shifts towards sustainable and energy efficient modes of transport, as well as reduction goals in GHG, pollutants and oil consumption. Despite all efforts, the growth of the non-road modes of freight transport remains a strong challenge for Europe, as during 2001-2011 road-borne freight strengthened its share from 75 to $76 \%$ of the total inland intra-EU transport work (ton-km), whilst railways were reduced to $18 \%$ (from 19\%) and waterways maintained their portion of 6\% (Eurostat 2013).

The White Paper (EC 2011) acknowledges the fact that so far rising volumes of freight transport have outweighed efficiency gains in transport and new vehicle and fuel technologies alone will not be sufficient to meet the challenge of the sustainable EU transport by 2030 and 2050. Therefore, 'specially developed freight corridors optimised in terms of energy use and emissions, minimising environmental impacts, but also attractive for their reliability, limited congestion and low operating and administrative costs will be also necessary'. Amongst the ten key benchmarks of the White Paper (EC 2011) for the achievement of a competitive and resource-efficient transport system are included:

- 'a 30\% shift of road freight over $300 \mathrm{~km}$ to other modes such as rail or waterborne transport by 2030, and more than 50\% by 2050, facilitated by efficient and green freight corridors';

- 'a fully functional and EU-wide multimodal TEN$T$ 'core network' by 2030, with a high-quality and capacity network by 2050 and a corresponding set of information services'.

Both benchmarks are relevant to 'the optimisation of the performance of multimodal logistic chains, including the greater use of more energy-efficient modes', which constitutes one of the three pillars of the White Paper (EC 2011) strategy on transport. Furthermore, it is also stated that 'on the coasts, more and efficient entry points into European markets are needed, avoiding unnecessary traffic crossing Europe. Seaports have a major role as logistics centres and require efficient hinterland connections. Their development is vital to handle increased volumes of freight both by short sea shipping within the EU and with the rest of the world', and with specific significance for this paper, the previous statement closes by the sentence: 'inland waterways, where unused potential exists, have to play an increasing role in particular in moving goods to the hinterland and in linking the European seas. Towards meeting this objective, the knowledge and experience gained through the NAIADES I (2006-2013) and NAIADES II (2014-2020) programmes for the 'Navigation and Inland Waterway Action and Development in Europe', as well as the implementation of their supporting programmes PLATINA I and II, will play a major role (http://www.naiades.info).

The role of inland navigation in a sustainable transport system has been recently presented by Caris et al. (2014) within the context of intermodal transportation and studied by Rohács and Simongáti (2010), whilst the significance of the Danube River as a vital transport artery for the EU and the European continent has been presented in the work of Radmilović and Dragović (2007), and more recently by Mihic et al. (2011), and Radmilović and Maraš (2011). Furthermore, the environmental impact of inland navigation in the context of the air pollution produced by the riverboats has been addressed by Den Boer (2011), whilst the work by Radojcic (2009) was conducted with reference to Danube and that by Ljevaja (2011) and Radonjić (2011) for Serbia.

Amongst the people of the Balkans, the concept of the Axios-Morava navigation route connecting the eastern Mediterranean (via the Aegean Sea) with thr Danube River dates back to at least five generations, but the first comprehensive approach into its feasibility was presented by Jovanovski (2011) and has lately resurfaced as a project proposition mainly due to the expressed international interest in the project amidst a mounting pressure to develop sustainable transport corridors in Europe (Corres 2014; Dunčić, Lukić 2013; Radaković 2012). The ongoing political and economic reform within the Balkans makes the region the ideal playing field for each of the great powers i.e. USA (via NATO and EU), Russia (via Serbia) and China (via Serbia), in their effort to establish their presence and exercise their influence in the future affairs of the wider region.

This paper makes a unique contribution to existing literature, because it examines the Axios-Morava waterway within the context of the current White Paper (EC 2011) strategy on the EU transport. More specifically, the comparative analysis with the competing modes of road and rail transport of freight in terms of fuel use and atmospheric impacts highlights the challenges associated with the proposed modal shift with regard to energy efficiency and environmental (atmospheric) quality.

From this point onwards, the paper is organised as follows: The description of the Axios-Morava waterway link is presented in Section 1, whilst Section 2 highlights the international interest on the development of this link into a navigable route over the years. Section 3 describes the operational characteristics of the three competing transport modes (i.e. the waterway, rail and road service). The methodology for estimating the energy efficiency and air quality performance for each service is given in section 4 . The results of the comparison analysis are illustrated and discussed in Section 5. Conclusions and suggestions are presented in last Section. 


\section{Description of the Waterway Link}

The Danube River with a length of around $3000 \mathrm{~km}$ is the longest river in the $\mathrm{EU}$ and through its connection with the Rhine-Main $(500 \mathrm{~km})$ forms a fully navigable link between the North Sea (Rotterdam) and the Black Sea (Constanta), thus being an integral part of the Trans European Transport Network (TEN-T). The Danube passes through ten riparian countries (seven EU member states) and its basin extends to nine more, contributing to the socio-economic growth of the Central, Eastern and South-Eastern region of the European continent.

The proposed waterway link essentially utilizes the route offered by the Axios (or Vardar) River at the south and that of the Morava River over the north section (Fig. 2). Axios is the longest river that runs through Greece and FYROM, having a length of $275 \mathrm{~km}$, with a width presently ranging from 50 to $600 \mathrm{~m}$ and a depth, which can reach up to $4 \mathrm{~m}$. It extends northbound into FYROM territory under the name Vardar and joins the Morava River further in north. The Morava runs over $345 \mathrm{~km}$ through Serbian land and joins the Danube at $50 \mathrm{~km}$ east of Belgrade. The overall length of the waterway link between the Aegean Sea and the Danube River is equal to $650 \mathrm{~km}$, thus offering a $1200 \mathrm{~km}$ shorter route between the eastern Mediterranean and Central Europe (via the Black Sea).

However, making the Axios-Morava waterway navigable and ready for service will require extensive construction work, which will involve the building of canals (a short main canal and 4-5 lateral), wharfs, numerous locks and dams, as well as the opening of new roads and other supporting facilities. To this effect, the accumulated knowledge and experience in the building and operation (incl. maintenance) of navigable waterways is adequate for such undertaking. In terms of added value, the construction and operation of the waterway link will bring socio-economic growth in the region, whilst the river-borne trade will boost the productivity of the agricultural sector which is dominant in this peripheral area of Europe.

\section{International Interest}

Although the discussion for the navigability of Morava dates back to the 1840s, the development of the entire Axios-Morava link into a navigable waterway was of a scale and character, which was bound to require international intervention. In 1907, the American government established in New Jersey the American engineering commission for the observation of the Morava-Vardar waterway. The Balkan wars of 1912-1913 and the regional instabilities of the interwar period put the project aside. After the end of World War II and up to the beginning of the $80 \mathrm{~s}$, the political orientation of former Yugoslavia was not favouring the co-operation with the west and most importantly Greece as a riparian country, whilst the emergence of ethnic tensions between Serbia and the ex-Yugoslavian republics during the 80s and their eventual engagement in war during the 90s (terminated with the NATO bombing of Serbia in 1999) inevitably placed the region under other priorities.

The big change came recently through the attraction of the Chinese interest in investments throughout the Balkans. After visiting more than thirty locations along the route, during a period of three months, the Chinese have concluded that the project is technically feasible and funding will follow the example of COSCO's concession in the Port of Piraeus. Combining China's interest in this project, it is important to note that with major Chinese investments in the Ports of Piraeus and Thessaloniki, and with similar projects in the infrastructure sector in the countries of southern and South-Eastern Europe, "China creates an alternative route for the entry of products in Europe, which is the largest market and which, unlike the ports of northern Europe, it would be for 99 years under its influence and management", significantly boosting its geopolitical position (Corres et al. 2014).

Apart from Greece, FYROM and Serbia, which are directly involved, the project is also attracting directly or indirectly the attention of Russia, the EU and the USA. In this context, there is already Russian interest in the privatization plan of the Hellenic Railways and the Port

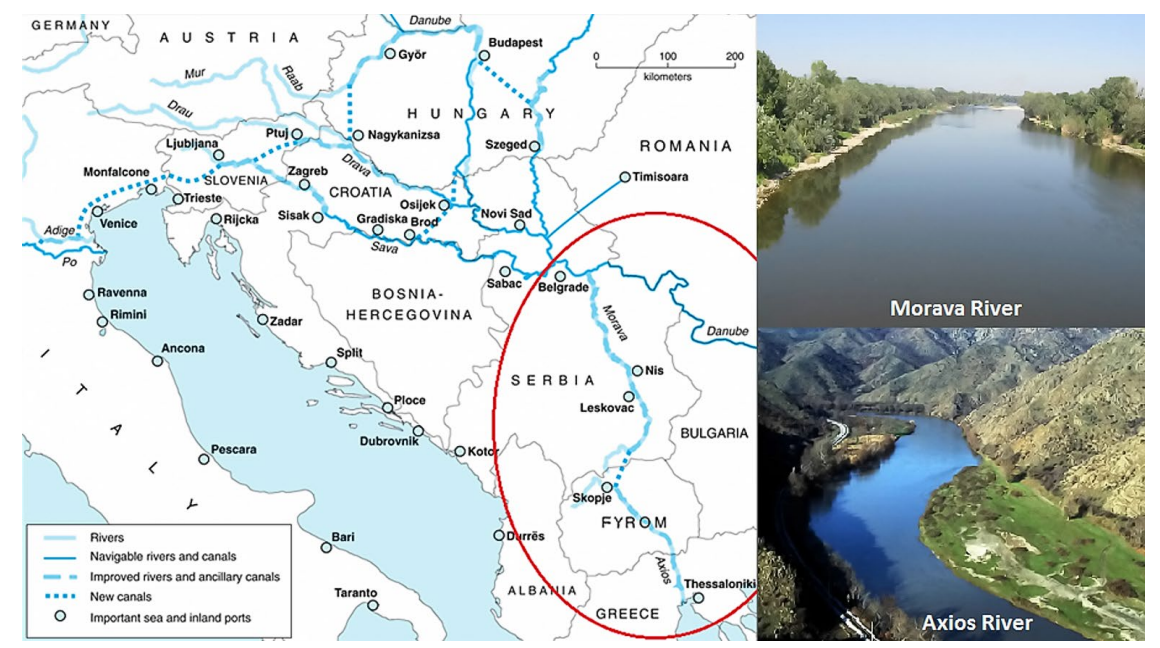

Fig. 2. Axios-Morava inland waterway (Zepp-LaRouche 2012) 
of Thessaloniki, whilst the EU is bound to exercise its influence through:

- Serbia's accession negotiations with the EU which started on 1 January 1 2014;

- the policy for river transportation (NAIADES II) which integrates it into the European Transport Networks (TEN-T) with a substantial budget for infrastructure projects;

- the socio-economic interest in the developmental character of the project.

Last, but not least, although the project does not clearly relate to the USA interests in the transport sector, it is otherwise significant within the framework of geopolitical influence. A possible long-term presence of Chinese and/or Russian interests in the region could clash with other USA priorities especially after the recent developments in Ukraine.

\section{Operational Profile of Freight Transport Services}

The performance of a waterway link is mainly related to the riverboats, which use it and specifically to their design parameters which are dictated by the navigational constraints imposed upon them. Riverboat water and air draft, length and beam are tailored to the waterway natural and man-made characteristics. For example, navigability through the entire stretch of the Danube River allows a maximum loaded draft of around $2.0 \mathrm{~m}$ to account for adequate clearance at swallow waters. In general, beam and length are restricted by the size of locks with length being also limited by waterway bends and air draft by the height of bridges.

A concise presentation of the basic designs (selfpropelled, barges etc.) of freight riverboats engaged in Europe is given in the work by Radmilović and Maraš (2011), whilst detailed descriptions of the various designs involved in the European waterway network in general and for the Danube River in particular can be obtained through the reporting of the SPIN-T programme (http:// spin-tn.factline.com). The types of riverboats, which are currently active in Danube range from dry bulk carriers and tankers to general cargo (incl. containers) carriers and Ro-Ro. Self-propelled riverboats vary from $38-40 \mathrm{~m}$ long having a payload capacity of about 300 tons at $2.5 \mathrm{~m}$ draft to $110 \mathrm{~m}$ long with on average 1900 tons payload at the same draft. In recent times, even considerably larger vessels have become usual on the Rhine River having a length of up to $135 \mathrm{~m}$, a beam of up to $17 \mathrm{~m}$ and a payload of about 3500 tons at only
$2.5 \mathrm{~m}$ draft. Barges range between $70.0-76.5 \mathrm{~m}$ in length, a beam between 9.5-11.4 $\mathrm{m}$ and a cargo carrying capacity, which is mainly determined by the available depth of the waterway. Indicative draft for a given payload of a typical Danube barge $(77 \times 11 \times 2.8 \mathrm{~m})$ is: $1.0 \mathrm{~m}$ for $300-$ 400 tons, $1.5 \mathrm{~m}$ for $700-800$ tons, $2.0 \mathrm{~m}$ for $1100-1200$ tons, $2.5 \mathrm{~m}$ for $1500-1600$ tons, $2.8 \mathrm{~m}$ for 1800 tons and $4.0 \mathrm{~m}$ for 4000 tons. Barge convoys usually consist of 2 to 6 barges, which carried in various combinations in tandem and/or in parallel by a push boat (or very rarely by a pull/tug boat) of appropriate power. Finally, a selfpropelled riverboat may also carry 1 or 2 barges abreast.

Indicative data with regard to the riverboat characteristics which would be suitable for the Axios-Morava waterway link can be obtained through reference to the fleet of the largest river shipping company in Serbia, 'Yugoslav River Shipping'/'Jugoslovensko Recno Brodarstvo (JRB)'(http://www.jrb.rs). The main particulars of the JRB fleet are synoptically shown in Table 1 and their dry cargo self-propelled riverboat (Fig. 3) was selected for the Axios-Morava waterway service to be operated at the fully loaded condition of 2000 tons (at $2.7 \mathrm{~m}$ water draft).

For the purposes of providing a level-playing field for the comparison of the energy, carbon and air quality performance of the three competing freight transport services, the land-based vehicles were assumed to operate over the route between Thessaloniki and Belgrade and the equivalence of their utilisation with the riverboat's payload was achieved as shown in Fig. 4. With regard to the road service the 'fastest' (as opposed to the shortest) distance between Thessaloniki and Belgrade based on the route which offers minimum 'flow resistance' and was found to be equal to $677 \mathrm{~km}$, whilst the

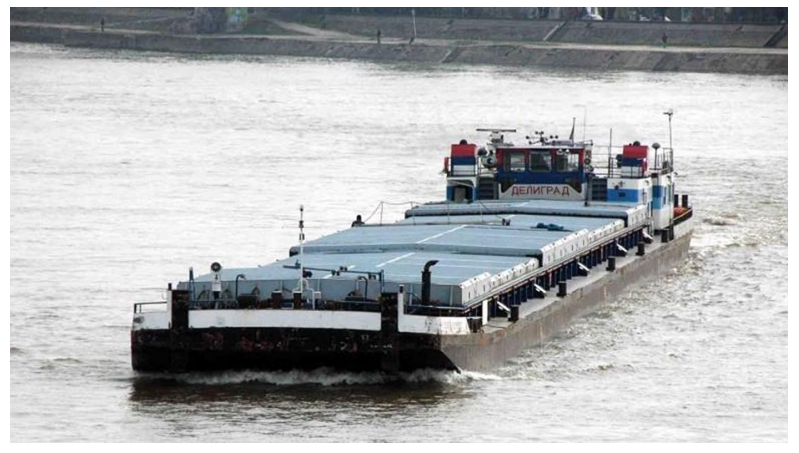

Fig. 3. JRB's self-propelled dry cargo riverboat (http://www.jrb.rs)

Table 1. JRB's riverboat fleet

\begin{tabular}{|l|l|c|c|c|}
\hline \multicolumn{2}{|c|}{ Riverboat type } & Number & Average payload capacity [tons] & Average propulsion power [kW] \\
\hline \multirow{2}{*}{ Barges } & Dry cargo & 62 & 1732 & - \\
\cline { 2 - 5 } & Liquid cargo & 58 & 1386 & 1276 \\
\hline \multirow{2}{*}{ Self-propelled } & Dry cargo & 1 & 1892 & 551 \\
\cline { 2 - 5 } & Liquid cargo & 1 & 1246 & 1199 \\
\hline \multirow{2}{*}{ Push-boats } & 14 & - & 885 \\
\hline \multicolumn{2}{l|l}{ Tugboats } & 2 & - & - \\
\hline
\end{tabular}




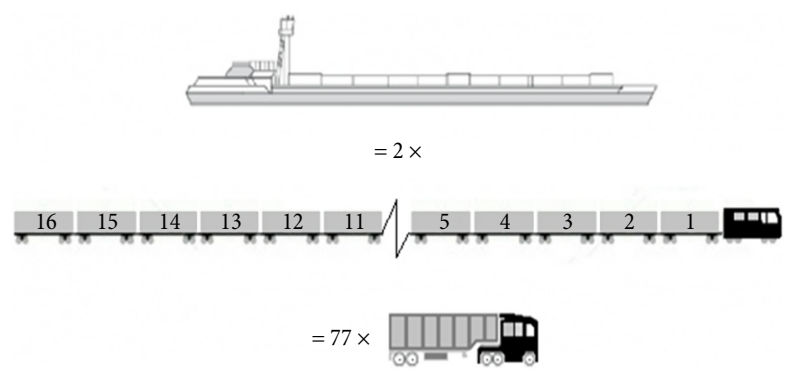

Fig. 4. Number of vehicles for payload capacity equivalence of 2000 tons

corresponding railway link stretches over the distance of $664 \mathrm{~km}$.

For the payload equivalence, the road service was assumed to employ 77 diesel-trucks each of 40 tons gross weight (26 tons payload capacity), whilst the railway service employed two freight train formations each of nearly 1500 tons gross weight consisting of a diesel locomotive and 16 wagons each of 84 tons gross weight (61 tons payload capacity). The vehicles of both landbased services are typical of the heaviest types operating in this region.

A critical performance parameter in waterway freight services is that of transit time, as it is widely acknowledged that it is the slowest mode of motorized transport. This stems basically from the fact that cargo riverboats have a full-body hull which inevitably restricts their speed in favour of increased cargo carrying capacity under the waterline, whilst sailing resistance increases at low clearances between the river-bed and the keel. Furthermore, waterway authorities usually impose speed limits to avoid damage to riverbanks and wharfs produced by the hull wake, which can be profound in swallow waters especially near the critical (hull) speed regime. During sailing in swallow waters, squat effects must also be controlled through the reduction of speed. Away from these constraints, low draft vessels can reach service speeds of $20 \mathrm{~km} / \mathrm{h}$, but transit times are also prolonged due to delays at the locks (waiting at entry and lock transit) and in many cases because only daytime navigation is allowed. On this basis, the selected riverboat will require on average $50 \%$ of its MCR of $1300 \mathrm{~kW}$ to develop an average speed of $10 \mathrm{~km} / \mathrm{h}$ through the relatively swallow $(<4.0 \mathrm{~m}$ ), occasionally narrow (down to $50 \mathrm{~m}$ ) and 'meandering' Axios-Morava waterway, before it enters the less restrictive the Danube River. At this sailing speed, the passage through the entire $650 \mathrm{~km}$ route will take 65 hours, whilst the total transit time including 11 canal approaches and transits, as well as five 12-hour overnight stops is expected to last 180 hours (or 7.5 days) - Corres et al. (2014).

Based on the data presented by popular truck manufacturers (MAN Trucks 2014; Volvo Trucks 2014), the rated power of the truck's engine was assumed to be equal $315 \mathrm{~kW}$ ( $420 \mathrm{hp}$ ) being typical of modern tractors suitable to international haulage within the South-Eastern European region for the carriage of a maximum payload of 26 tons (40 tons gross weight). At the fully loaded condition, the truck is capable of developing an average speed of $80 \mathrm{~km} / \mathrm{h}$, which will cover the ThessalonikiBelgrade distance in 8.5 hours (excl. stoppage time). Similarly, drawing on information relevant to modern diesel locomotives specifically adapted for cross-border operation in Europe (GE Transportation 2014), the traction of the 1500 gross tons train will require an engine of $2760 \mathrm{~kW}(3700 \mathrm{hp})$ rated power which can accommodate the railway gradients within the Balkan Peninsula and will offer an average train speed of $70 \mathrm{~km} / \mathrm{h}$ for covering the Thessaloniki-Belgrade distance in 9.5 hours (excl. stoppage time).

\section{Energy Efficiency and Environmental Performance}

At a time of increased commercial competition and fuel prices, the energy efficiency offered by transport services is very important as fuel expenditure constitutes a major part of their overall cost function. However, apart from the internal (private) costs, transport companies are faced with the challenge of reducing their negative externalities mainly in order to alleviate the social costs amidst the emerging wave of cost internalization, but also in an effort to improve their commercial image. Transport-related exhaust emissions have atmospheric impacts at global, regional and local level causing significant damage to the natural and built environment, and most importantly to human health. Amongst them, $\mathrm{CO}_{2}, \mathrm{SO}_{2}, \mathrm{PM}$ and $\mathrm{NO}_{\mathrm{x}}$ are widely acknowledged for their most important impacts (Table 2). However, the fact that energy savings reduce emissions either directly (for $\mathrm{CO}_{2}$ ) or indirectly (for the other pollutants) presents transport companies with a powerful incentive to improve their energy efficiency record in order to cut down on fuel costs and improve their environmental performance too.

Table 2. Impact of exhaust emissions

\begin{tabular}{|c|l|}
\hline Emission & \multicolumn{1}{c|}{ Impact } \\
\hline $\mathrm{CO}_{2}$ & Global warming - climate change \\
\hline $\mathrm{SO}_{2}$ & Acidification, eco-toxicity, human toxicity \\
\hline $\mathrm{PM}$ & Human toxicity, summer smog \\
\hline $\mathrm{NO}_{\mathrm{x}}$ & $\begin{array}{l}\text { Acidification, eutrophication, eco and human } \\
\text { toxicity, summer smog }\end{array}$ \\
\hline
\end{tabular}

The energy and emission performance of the three modes of freight transport was modelled according to an activity-based methodology, which utilised the operational parameters of the vehicles involved and the fuel consumption and exhaust emission coefficients of their engines. In each transport mode, the latest (strictest) engine emission standards were considered.

More specifically, with regard to the $\mathrm{NO}_{\mathrm{x}}$ and $\mathrm{PM}$ emission coefficients of the riverboat, the strictest standards of Directive 2004/26/EC - Stage IIIA currently applicable to inland navigation were assumed, as they cover all new engines from 01/07/2007. Furthermore, the $\mathrm{SO}_{2}$ emission coefficient was estimated using the 
LR (1995) expression according to the work by Cooper and Gustafsson (2004) for Medium Speed Diesel (MSD) engine operation on fuel with $10 \mathrm{ppm}$ sulphur, being the upper limit for inland waterway transport from 01/01/2011 according to Directive 2009/30/EC. For the $\mathrm{NO}_{\mathrm{x}}$ and $\mathrm{PM}$ emissions of the railway service, the Stage IIIB standards of Directive 2004/26/EC were assumed as they currently apply to all new diesel-locomotive engines from $01 / 01 / 2012$, whilst their $\mathrm{SO}_{2}$ emissions were based on the $10 \mathrm{ppm}$ sulphur limit of fuel imposed also on rail by the aforementioned Directive 2009/30/EC from 01/01/2011. Finally for the $\mathrm{NO}_{\mathrm{x}}$ and $\mathrm{PM}$ emissions of the truck engines, their compliance with the recently (01/01/2013) enforced EURO VI standards was assumed (Directive 2003/17/EC), whilst their $\mathrm{SO}_{2}$ emissions were also based on the $10 \mathrm{ppm}$ sulphur limit for road diesel (EN 590:2009). The $\mathrm{NO}_{\mathrm{x}}, \mathrm{PM}$ and $\mathrm{SO}_{2}$ emission limits applicable to the engines associated with the three modes of transport service are shown in Table 3.

Table 3. Engine emission limits per transport mode

\begin{tabular}{|l|c|c|c|}
\hline Emission coefficient & Riverboat & Truck & Rail \\
\hline $\mathrm{NO}_{\mathrm{x}}[\mathrm{g} / \mathrm{kWh}]$ & 6.0 & 0.4 & 2.0 \\
\hline $\mathrm{PM}[\mathrm{g} / \mathrm{kWh}]$ & 0.2 & 0.01 & 0.025 \\
\hline $\mathrm{SO}_{2}[\mathrm{~g} / \mathrm{kWh}]$ & \multicolumn{3}{|c|}{$4.2 \cdot 10^{-3}$} \\
\hline
\end{tabular}

The fuel consumption of the riverboat engine was based on the work by Georgakaki and Sorenson (2004) prepared for the ARTEMIS project for the specific vessel class and operating (payload and water depth) conditions. Truck fuel consumption was obtained from EMEP/EEA (Ntziachristos et al. 2013a) taking also into consideration recently released manufacturer's data (Eurostat 2013), whilst that of the railway service was calculated according to the methodology adopted by Den Boer et al. (2011) for the European average (hilly terrain) and EMEP/EEA (Norris et al. 2013b). Similar to the riverboat's engine, the fuel consumption of the landbased engines (i.e. truck and rail) was representative of the vehicles' technology and operating conditions most relevant to the case under consideration.

Finally, as there is no $\mathrm{EU} \mathrm{CO}$ legislation for freight transport (exempt for vans), the values for the $\mathrm{CO}_{2}$ emission coefficient, Net Calorific Value (NCV) and the density of the diesel/gas oil were assumed according to the default values of the 2006 IPCC guidelines (Eggleston et al. 2006). The summary of the fuel and $\mathrm{CO}_{2}$ relevant parameters are shown in Table 4.

Table 4. Engine fuel parameters and $\mathrm{CO}_{2}$ factor per transport mode

\begin{tabular}{|l|c|c|c|}
\hline \multicolumn{1}{|c|}{ Parameter } & Riverboat & Truck & Rail \\
\hline Fuel consumption [lit./km] & 14.8 & 0.35 & 5.75 \\
\hline $\mathrm{CO}_{2}$ [g-CO 2 /g-fuel] & \multicolumn{3}{|c|}{3.1863} \\
\hline Fuel NCV [MJ/kg] & \multicolumn{3}{|c|}{43.0} \\
\hline Fuel density [kg/lit.] & \multicolumn{3}{|c|}{0.85} \\
\hline
\end{tabular}

\section{Results and Discussion}

The energy and fuel consumed as well as the $\mathrm{CO}_{2}$ produced during the single-leg (one-way) movement of 2000 tons of freight by the three alternative modes of transport are shown in Fig. 5.

Overall the waterway service was found to be significantly superior to that of the road and slightly better than the rail. More specifically, the fuel consumed by the road service was almost double to that of the waterway, whereas the latter was $13.5 \%$ less fuel thirsty than the rail service. Taking into account that all transport modes use fuel of identical specification, the consumed energy (MW.h) and the amount of produced $\mathrm{CO}_{2}$ emissions followed the comparison of the fuel consumption.

The energy and carbon efficiencies of the three services are shown in Fig. 6, where the waterway and railway services maintain their superiority in comparison to the road. It is important to note that although this efficiency ranking is consistent with the results of various studies comparatively presented in the work by McKinnon and Piecyk (2010), the observed $\mathrm{CO}_{2}$ efficiency of the examined waterway, road and diesel railway service is lower than the reported average of 31 , 62 and $37 \mathrm{~g}-\mathrm{CO}_{2} /$ ton- $\mathrm{km}$, respectively. This difference is mainly attributed to the vehicles' capacity utilisation, which in the current analysis was assumed to be 100\% for aiding the comparison across all transport modes, whilst real-world load factors range between $55-65 \%$ depending on transport mode, cargo type and most importantly on the prevailing market conditions.

In an effort to distinguish between the produced $\mathrm{CO}_{2}$ emissions which have a global impact and those emissions which are important with regard to local and regional air quality (i.e. $\mathrm{SO}_{2}, \mathrm{PM}$ and $\mathrm{NO}_{\mathrm{x}}$ ), the latter are presented separately in Fig. 7. The waterway service produces the lowest $\mathrm{SO}_{2}$ emissions, although they do not offer a sizable advantage in comparison to the road and rail alternative. In terms of $\mathrm{PM}$ and $\mathrm{NO}_{\mathrm{x}}$ emissions, the road service is by far the best option, whilst that of the railway has an improved performance in comparison to the waterway service. This is mainly attributed to the stricter $\mathrm{PM}$ and $\mathrm{NO}_{\mathrm{x}}$ emission limits enforced on the new truck and diesel locomotives, as opposed to the more relaxed which are applicable to new riverboat engines.

In addition to this specific observation, it is important to note that in general the comparative picture of the air pollution performance of inland navigation is even worse. As the introduction of emission limits in transport discriminates between existing and new engines, under real-world circumstances, the emission profile of the existing waterway fleet in Europe falls very short of the post-2006 limits of the Directive 2004/26/EC applied in this analysis. This is attributed to the slow rate of replacement of riverboat engines, as it is usually limited to retrofitting rather the replacement of the vessel. There are numerous pre-1974 riverboats having $\mathrm{NO}_{\mathrm{x}}$ and $\mathrm{PM}$ emission coefficients, which are nearly double the currently permissible standards for post-2007 riverboat engines. At the same time, the renewal of the truck fleet is 


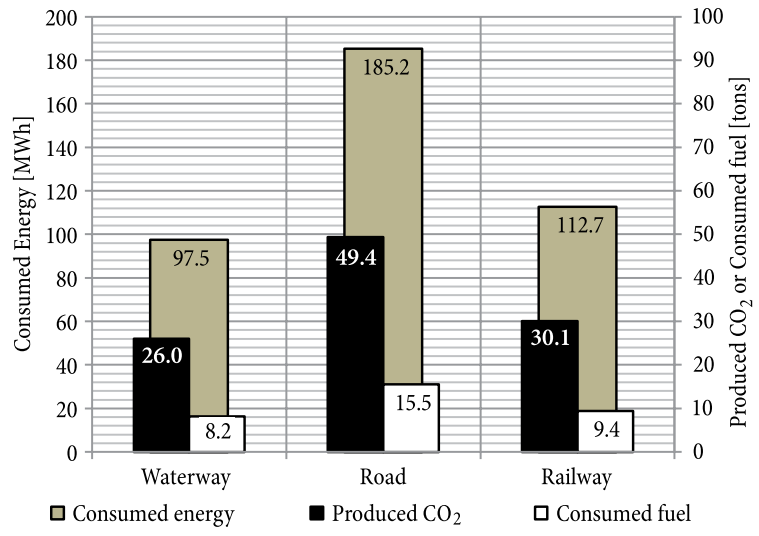

Fig. 5. Energy consumption and $\mathrm{CO}_{2}$ emission per mode of transport service

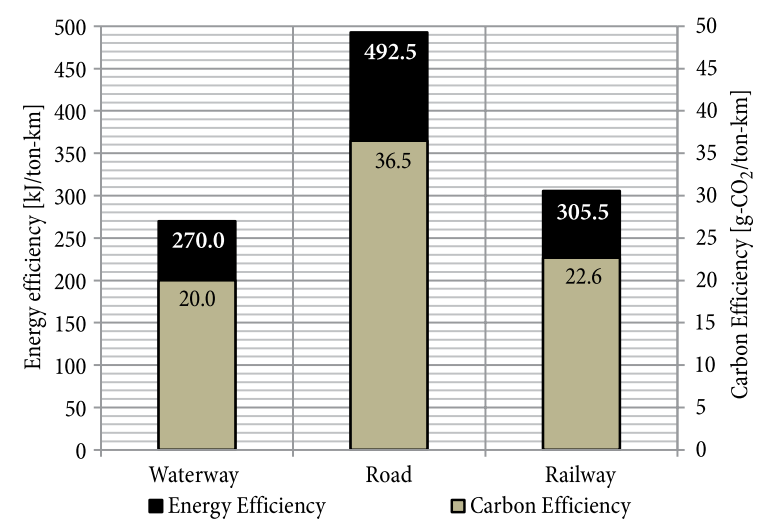

Fig. 6. Energy and carbon efficiency per mode of transport service

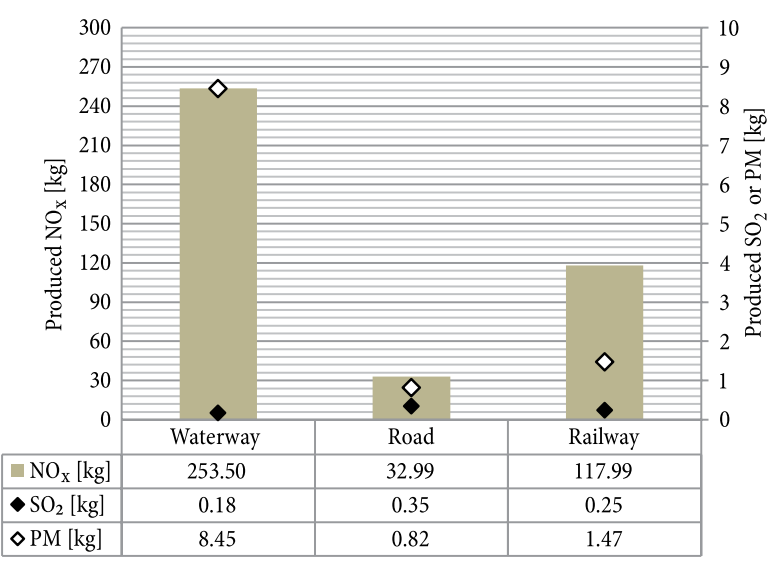

Fig. 7. Air pollutants per mode of transport service

much faster and the on-going expansion of rail electrification is bound to shrink the share of diesel traction.

The improvement of the air quality performance of inland navigation is very important, because the air pollutant receptors are closer and hence more vulnerable to damage than those exposed to the coastal and ocean-going ship operations. Of course, similar to the case of short sea shipping, reducing the exhaust emissions of riverboats requires the use of 'cleaner' fuels and/ or the introduction of exhaust treatment technologies (e.g. scrubbers).
However, the additional investments required to improve the environmental (atmospheric) performance of inland navigation are bound to increase the cost of the waterway services and make them commercially disfavoured in comparison to the other competing modes of transport. In an effort to avert the reverse modal-shift for inland navigation, it is necessary to realize that the attainment of sustainable transport in Europe requires an approach, which will engage all stakeholders in sharing the risks and opportunities, and amongst them governments have a 'governing' role to play in providing the correct policies (incl. appropriate incentives) to meet this challenge.

\section{Conclusions}

Inland waterways can make a significant contribution towards achieving transport sustainability in Europe and the EU in particular, and within the economically growing region of South-Eastern Europe, their unused potential needs to be fully explored.

It has been shown that the Axios-Morava waterway through its connection with the Danube River offers the ability to link the eastern Mediterranean with Central Europe in an energy and carbon efficient manner. However, its impact on the regional and local air quality must be significantly improved in order to successfully compete against its land-based alternatives of road and rail freight transport.

The paper reveals the need to develop European transport policies, which will provide transport operators with the economic incentives and financial mechanisms to support the necessary infrastructural and operational investments for the utilization of waterway services. This will not only make these services commercially sustainable, but also it will accelerate the establishment of green logistics particularly in environmentally sensitive areas, which provide access to and from the European hinterland.

\section{References}

Caris, A.; Limbourg, S.; Macharis, C.; Van Lier, T.; Cools, M. 2014. Integration of inland waterway transport in the intermodal supply chain: a taxonomy of research challenges, Journal of Transport Geography 41: 126-136.

http://dx.doi.org/10.1016/j.jtrangeo.2014.08.022

Cooper, D.; Gustafsson, T. 2004. Methodology for Calculating Emissions from Ships: 1. Update of Emission Factors. Assignment for Swedish Environmental Protection Agency. 47 p. Available from Internet: http://www.smed.se/wp-content/ uploads/2011/05/SMED_Report_2004_4.pdf

Corres, A. 2014. From the Aegean Sea to the European Rivers: The Vardar-Morava-Danube Link. Lecture at the Hellenic Institute of Marine Technology. Scheduled for 14/01/2014. $42 \mathrm{p}$.

Corres, A.; Tselentis, B.; Tzannatos, E. 2014. An inland waterway option for sustainable freight transport in Southeastern Europe, Journal of Maritime Research 11(2): 17-24.

Costa, P. 2013. Global trade flows: a key component of the Union's sustainability equation, in TEN-T Days 2013: Connecting Europe - on the Move to the New TEN-T, 16-18 October 2013, Tallinn, Estonia. 
Den Boer, E. 2011. Instruments to Reduce Pollutant Emissions of the Existing Inland Vessel Fleet: Position Paper for International Workshop 'Emissions from the Legacy Fleet'. Delft, Netherlands. 15 p. Available from Internet: http:// www.cedelft.eu/publicatie/instruments_to_reduce_pollutant_emissions_of_the_existing_inland_vessel_fleet/1209

Den Boer, E.; Otten, M.; Van Essen, H. 2011. Comparison of Various Transport Modes on a EU Scale with the STREAM Database. Report for STREAM International Freight 2011. Delft, Netherlands. 103 p. Available from Internet: http:// www.shortsea.be/html_nl/publicaties/documents/CEDelftSTREAMInternationalFreight2011.pdf

Dunčić, D.; Lukić, J. 2013. The project to construct the Danube-Morava-Vardar-Aegean canal, in 24th Conference "Danube - River of Cooperation", 24 September 2013, Belgrade, Serbia.

EC. 2011. White Paper: Roadmap to a Single European Transport Area - Towards a Competitive and Resource Efficient Transport System. COM(2011) 144 final. 28.3.2011, Brussels. Available from Internet: http://eur-lex.europa.eu/LexUriServ/LexUriServ.do?uri=CELEX:52011DC0144:EN:NOT

EC. 2009. Directive 2009/30/EC of the European Parliament and of the Council of 23 April 2009 amending Directive 98/70/ EC as Regards the Specification of Petrol, Diesel and GasOil and Introducing a Mechanism to Monitor and Reduce Greenhouse Gas Emissions and Amending Council Directive 1999/32/EC as Regards the Specification of Fuel Used by Inland Waterway Vessels and Repealing Directive 93/12/EEC.

EC. 2004. Directive 2004/26/EC of the European Parliament and of the Council of 21 April 2004 Amending Directive 97/68/ EC on the Approximation of the Laws of the Member States relating to Measures Against the Emission of Gaseous and Particulate Pollutants from Internal Combustion Engines to be Installed in Non-Road Mobile Machinery.

EC. 2003. Directive 2003/17/EC of the European Parliament and of the Council of 3 March 2003 Amending Directive 98/70/ EC Relating to the Quality of Petrol and Diesel Fuels.

Eggleston, S.; Buendia, L.; Miwa, K.; Ngara, T.; Tanabe, K. (Eds.). 2006. 2006 IPCC Guidelines for National Greenhouse Gas Inventories. Intergovernmental Panel on Climate Change (IPCC). Available from Internet: http:// www.ipcc-nggip.iges.or.jp/public/2006gl

EN 590:2009. Automotive Fuels. Diesel. Requirements and Test Methods.

Eurostat. 2013. Energy, Transport and Environment Indicators: 2013 Edition. 252 p. http://dx.doi.org/10.2785/4663

Georgakaki, A.; Sorenson, S. C. 2004. Report on Collected Data and Resulting Methodology for Inland Shipping. Prepared for ARTEMIS project, DG TREN-FP5. Copenhagen, Denmark.

GE Transportation. 2014. PowerHaul Series Locomotive. Available from Internet: http://www.getransportation.com/locomotives/locomotives/power-haul\# overview

Gouvernal, E.; Rodrigue, J-P.; Slack, B. 2012. The divergence of regionalization: the challenges of the Mediterranean ports of Europe, in Proceedings of the International Association of Maritime Economists Conference (IAME 2012), 6-8 September 2012, Taipei, Taiwan.

Jovanovski, D. 2011. Morava-Vardar (Axios) navigation route, in Danubius: Journal of Regional Cooperation - Časopis za regionalnu saradnju. Available from Internet: http:// danube-cooperation.com/danubius/2011/11/28/moravavardar-axios-navigation-route

Ljevaja, D. 2011. Impact of emissions of marine diesel engines to air pollution on the example of the Yugoslav river shipping, International Journal for Traffic and Transport Engineering 1(3): 149-157.
LR. 1995. Marine Exhaust Emissions Research Programme. Lloyd's Register (LR), London, UK.

MAN Trucks. 2014. MAN Vehicles for Long-Haul Transport. Available from Internet: http://www.truck.man.eu/global/ en/long-haul-transport/model-comparison/Model-comparison.html

McKinnon, A. C.; Piecyk, M. 2010. Measuring and Managing $\mathrm{CO}_{2}$ Emissions in European Chemical Transport. The European Chemical Industry Council (CEFIC). 41 p.

Mihic, S.; Golusin, M.; Mihajlovic, M. 2011. Policy and promotion of sustainable inland waterway transport in Europe Danube River, Renewable and Sustainable Energy Reviews 15(4): 1801-1809.

http://dx.doi.org/10.1016/j.rser.2010.11.033

Norris, J.; Ntziachristos, L.; Samaras, Z.; Zierock, K.-H. 2013. Exhaust emissions from road transport, in EMEP/EEA Air Pollutant Emission Inventory Guidebook 2013: Technical Guidance to Prepare National Emission Inventories. European Environment Agency (EEA). 20 p. Available from Internet: http://www.eea.europa.eu/publications/emep-eeaguidebook-2013

Ntziachristos, L.; Samaras, Z.; Kouridis, C.; Samaras, C.; Hassel, D.; Mellios, G.; McCrae, I.; Hickman, J.; Zierock, K. H.; Keller, M.; Rexeis, M.; Andre, M.; Winther, M.; Pastramas, N.; Gorissen, N.; Boulter, P.; Katsis, P.; Joumard, R.; Rijkeboer, R.; Geivanidis, S.; Hausberger, S. 2013. Exhaust emissions from road transport, in EMEP/EEA Air Pollutant Emission Inventory Guidebook 2013: Technical Guidance to Prepare National Emission Inventories. European Environment Agency (EEA). 158 p. Available from Internet: http://www.eea.europa.eu/publications/emep-eea-guidebook-2013

Radaković, M. 2012. The Danube-Morava-Vardar-Aegean sea waterway, in N. J. Šarčević, E. S. Karanović (Eds.). Danube Strategy - Strategic Significance for Serbia, 175-184.

Radmilović, Z.; Dragović, B. 2007. The inland navigation in Europe: basic facts, advantages and disadvantages, Journal of Maritime Research 4(1): 31-46.

Radmilović, Z.; Maraš, V. 2011. Role of Danube inland navigation in Europe, International Journal for Traffic and Transport Engineering 1(1): 28-40.

Radojcic, D. 2009. Environmentally Friendly Inland Waterway Ship Design for the Danube River. Final Report of the "Danube Navigation" project No 9E0726.04. World Wide Fund for Nature International Danube-Carpathian Programme (WWF-DCP). $121 \mathrm{p}$.

Radonjić, A. 2011. Strategy to reduce pollution from Serbian pushboats, International Journal for Traffic and Transport Engineering 1(2): 59-72.

Rohács, J.; Simongáti, G. 2010. The role of inland waterway navigation in a sustainable transport system, Transport 22(3): 148-153.

UNCTAD. 2013. Review of Maritime Transport 2013. United Nations Conference on Trade and Development (UNCTAD). 204 p. Available from internet: http://unctad.org/ en/PublicationsLibrary/rmt2013_en.pdf

Volvo Trucks. 2014. Volvo FM - Designed for the Road. Available from Internet: http://www.volvotrucks.com/trucks/ global/en-gb/trucks/new-trucks/volvo_fm/Pages/volvo_ fm.aspx

Zepp-LaRouche, H. 2012. Building the Europe of the future: common development, not a debtors Union, Executive Intelligence Review 39: 40-62. 